\title{
Spatial distribution of Arctic bacterioplankton abundance is linked to distinct water masses and summertime phytoplankton bloom dynamics (Fram Strait, $79^{\circ} \mathrm{N}$ )
}

\author{
1 Magda G. Cardozo-Mino ${ }^{1,2^{*} \dagger}$, Eduard Fadeev ${ }^{1,2,3 \dagger}$, Verena Salman-Carvalho ${ }^{1,2,4}$, Antje \\ 2 Boetius ${ }^{1,2,5}$ \\ $3 \quad{ }^{1}$ Max Planck Institute for Marine Microbiology, Bremen, Germany \\ $4 \quad{ }^{2}$ Alfred Wegener Institute, Helmholtz Center for Polar and Marine Research, Bremerhaven, Germany \\ $5{ }^{3}$ Current affiliation: Department of Functional and Evolutionary Ecology, University of Vienna, \\ 6 Vienna, Austria \\ $7{ }^{4}$ Current affiliation: Department of Microbiology, University of Massachusetts Amherst, \\ 8 Massachusetts, MA, United States of America \\ $9{ }^{5}$ MARUM, University of Bremen, Bremen, Germany \\ $10 \dagger$ - equal contribution \\ 11 * Correspondence: \\ 12 Magda G. Cardozo-Mino \\ 13 mcardozo@mpi-bremen.de
}

14 Keywords: Arctic Ocean, Fram Strait, bacterioplankton, CARD-FISH, water column

\section{Abstract}

The Arctic is impacted by climate warming faster than any other oceanic region on Earth. Assessing the baseline of microbial communities in this rapidly changing ecosystem is vital for understanding the implications of ocean warming and sea ice retreat on ecosystem functioning. Using CARD-FISH and semi-automated counting, we quantified 14 ecologically relevant taxonomic groups of bacterioplankton (Bacteria and Archaea) from surface (0-30 m) down to deep waters $(2500 \mathrm{~m})$ in summerly ice-covered and ice-free regions of the Fram Strait, the main gateway for Atlantic inflow into the Arctic Ocean. Cell abundances of the bacterioplankton communities in surface waters varied from $10^{5}$ cells $\mathrm{mL}^{-1}$ in ice-covered regions to $10^{6}$ cells $\mathrm{mL}^{-1}$ in the ice-free regions, and were overall driven by variations in phytoplankton bloom conditions across the Strait. The bacterial classes Bacteroidia and Gammaproteobacteria showed several-fold higher cell abundances under late phytoplankton bloom conditions of the ice-free regions. Other taxonomic groups, such as the Rhodobacteraceae, revealed a distinct association of cell abundances with the surface Atlantic waters. With increasing depth $(>500 \mathrm{~m})$, the total cell abundances of the bacterioplankton communities decreased by up to two orders of magnitude, while largely unknown taxonomic groups (e.g., SAR324 and SAR202 clades) maintained constant cell abundances throughout the entire water column (ca. $10^{3}$ cells $\mathrm{mL}^{-1}$ ). This suggests that these enigmatic groups may occupy a specific ecological niche in the entire water column. Our results provide the first quantitative spatial variations assessment of bacterioplankton in the summerly ice-covered and ice-free Arctic water column, and suggest that further shift towards ice-free Arctic summers with longer phytoplankton blooms can lead to major changes in the associated standing stock of the bacterioplankton communities. 


\section{Introduction}

38

39

40

41

42

43

44

45

46

47

48

49

50

51

52

53

54

55

56

57

58

59

60

61

62

63

64

65

66

67

68

69

70

71

72

73

74

75

76

77

78

79

80

81

Atmospheric and oceanic warming has a substantial impact on the Arctic Ocean already today (Dobricic et al., 2016; Sun et al., 2016; Dai et al., 2019). The strong decline in sea ice coverage (Peng and Meier, 2018; Dai et al., 2019) and heat transfer by the Atlantic water inflow (BeszczynskaMöller et al., 2012; Rudels et al., 2012; Walczowski et al., 2017) will affect stratification of the water column and can lead to an increase in upward mixing of the Atlantic core water, a process also termed "Atlantification" (Polyakov et al., 2017). The main inflow of Atlantic water into the Arctic Ocean occurs through the Fram Strait (Beszczynska-Möller et al., 2011), making it a sentinel region for observing the ongoing changes in the Arctic marine ecosystem (Soltwedel et al., 2005, 2016). The Fram Strait is also the main deep-water gateway between the Atlantic and the Arctic Ocean. It hosts two distinct hydrographic regimes; the West Spitsbergen Current (WSC) that carries relatively warm and saline Atlantic water northwards along the Svalbard shelf (Beszczynska-Möller et al., 2012; von Appen et al., 2015), and the East Greenland Current (EGC) that transports cold polar water and sea ice southwards from the Arctic Ocean along the ice-covered Greenland shelf (de Steur et al., 2009; Wekerle et al., 2017).

Sea ice conditions have a strong impact on the seasonal ecological dynamics in Fram Strait and the whole Arctic Ocean (Wassmann and Reigstad, 2011), affecting light availability and stratification in the water column. The presence of sea ice and snow cover can repress the seasonal phytoplankton bloom in the water column through light limitation (Mundy et al., 2005; Leu et al., 2011), or change its timing, e.g. by increasing stratification of the surface waters once the ice melts (Korhonen et al., 2013). Also, sea-ice algae can make up a significant proportion of the annual productivity (Leu et al., 2011; Boetius et al., 2013; Fernández-Méndez et al., 2014). Previous summer observations in the Fram Strait already suggested that total cell abundances and productivity of bacterioplankton communities in surface waters are driven by environmental parameters associated with phytoplankton bloom dynamics (Fadeev et al., 2018), such as the availability and composition of organic matter (Piontek et al., 2015; Engel et al., 2019), with differences between ice-covered and ice-free regions (Piontek et al., 2014; Fadeev et al., 2018).

Long-term summer observations in the region, conducted in the framework of the Long-Term Ecological Research (LTER) site HAUSGARTEN, revealed strong ecological variations associated with the Atlantic Meridional Overturning Circulation (AMOC; Soltwedel et al., 2016). Warming events during the past decades influenced seasonal phytoplankton blooms by causing a slow but continuous increase in biomass, and a shift from diatom- to flagellate-dominated communities (Nöthig et al., 2015; Engel et al., 2017; Basedow et al., 2018). It has been recently observed that phytoplankton blooms show an increasing partitioning of the produced organic carbon into the dissolved phase (Engel et al., 2019), which may result in a more active microbial loop in the upper ocean and less export of particulate matter (Vernet et al., 2017; Fadeev et al., 2020). In times of a rapidly changing Arctic ecosystem, investigating structure and dynamics of bacterioplankton communities remains a key component to the understanding of current changes in this environment. However, so far, an assessment of associated responses of the key bacterial taxa responsible for an increased recycling is missing, especially with regard to shifts in standing stocks.

To date, the majority of Arctic bacterioplankton studies are performed using high-throughput sequencing of the 16S rRNA gene, which cannot be directly converted to absolute standing stock abundances of specific taxonomic groups due to PCR and other quantitative biases (Gloor et al., 2017; Kumar et al., 2017; Piwosz et al., 2020). Here we used semi-automatic CAtalyzed Reporter Deposition-Fluorescence In Situ Hybridization (CARD-FISH; Pernthaler et al., 2002). The power of 
82

83

84

85

86

87

88

89

90

91

92

93

94

95

96

97

98

99

100

101

102

103

104

105

106

107

108

109

110

111

112

113

114

115

116

117

118

119

120

121

122

123

124

125

126

this technique lies in the ability to acquire absolute abundance of the targeted taxonomic groups free of compositional effect (Amann et al., 1990). Besides the ability to target and quantify specific taxonomic groups, the retrieval of a positive hybridization signal furthermore indicates that the analyzed cell was alive and active before fixation (Amann et al., 1990; DeLong et al., 1999).

Automatization of the microscopic examination and counting procedure can reach a high-throughput standard (Schattenhofer et al., 2009; Teeling et al., 2012; Bižić-Ionescu et al., 2015; Bennke et al., 2016). Using CARD-FISH and semi-automated cell counting, we quantified cell abundances of 14 taxonomic groups in 44 samples, collected at 4 different water layers from surface $(15-30 \mathrm{~m})$ to the deep ocean $(2500 \mathrm{~m})$ in both, ice-free and ice-covered regions of the Fram Strait. The main objective of this study was to assess the standing stocks of key taxonomic groups in summerly Arctic bacterioplankton across the Strait. Using high-throughput data of bacterioplankton cell abundances we tested the following hypotheses: 1) in surface waters, the abundances of different bacterioplankton taxonomic groups are associated with phytoplankton bloom conditions, and are linked to the abundances of specific phytoplankton populations; 2) water depth structures the bacterioplankton communities, and 3) differences between communities in ice-covered and ice-free regions decrease with increasing water depth.

\section{Results and Discussion}

We investigated a total of 44 water samples from 11 stations that represented different hydrographic and biogeochemical conditions across the Fram Strait (Figure 1; Table S1). At each station, 4 different water layers were targeted: the surface mixed layer $(0-30 \mathrm{~m})$, epipelagic waters $(100 \mathrm{~m})$, deep mesopelagic waters (500-1000 m), and bathypelagic waters (1200-2500 m). Based on the known hydrography of the Strait (Rudels et al., 2012), and observed sea-ice conditions, the sampled stations were grouped into three distinct regions (Figure 1): the eastern ice-free region associated with the WSC (Beszczynska-Möller et al., 2012), the western ice-covered region associated with the EGC (de Steur et al., 2009), and the partially ice-covered region in the north-east that is associated with the highly productive ice-margin zone (further addressed as North- "N") (Hebbeln and Wefer, 1991; Perrette et al., 2011). At the time of sampling in June-July 2016, microscopy counts of phytoplankton communities and chlorophyll $a$ concentration, showed a late phytoplankton bloom across the Strait (Table S1; described in detail by Fadeev et al. 2020). The phytoplankton communities of the ice-covered EG and the ice-margin $\mathrm{N}$ stations were dominated by diatoms, in contrast to the ice-free HG stations that were dominated by Phaeocystis spp. These locally defined conditions correspond to an interannual trend of distinct phytoplankton bloom conditions observed in the western ice-covered EGC and the eastern ice-free WSC (Nöthig et al., 2015; Fadeev et al., 2018).

\subsection{Surface water bacterioplankton communities are affected by distinct phytoplankton bloom conditions}

Phytoplankton blooms in surface waters generally lead to an increased cell abundance of heterotrophic bacteria that are specialized on degradation of organic matter from algal exudates and phytodetritus (Buchan et al., 2014; Teeling et al., 2016). Previous observations in the Fram Strait, acquired using high-throughput sequencing of the 16S rRNA gene, revealed a strong influence of the summerly phytoplankton bloom conditions on the bacterioplankton communities (Wilson et al., 2017; Müller et al., 2018b), differing between the ice-covered and ice-free regions of the Strait (Fadeev et al., 2018). During our sampling period, distinct phytoplankton bloom communities in surface waters across the Strait were observed, with a Phaeocystis-dominated bloom in the ice-free HG stations, a diatom-dominated bloom in the ice-covered EG stations, and mixed diatoms and Phaeocystis populations bloom in the ice-margin N stations (Fadeev et al., 2020). Along with this, 
127 we observed significantly higher cell abundances in the surface water total bacterioplankton

128 communities of the HG and N stations $\left(13-21 \times 10^{5}\right.$ cells $\left.\mathrm{mL}^{-1}\right)$, as compared to the EG stations $(0.5-$ $2 \times 10^{5}$ cells $\mathrm{mL}^{-1}$; Kruskal-Wallis test; Chi square $=81.85, \mathrm{df}=2, p$-value $\left.<0.01\right)$. The communities

130 were dominated by bacterial cells that comprised $8-11 \times 10^{5}$ cells $\mathrm{mL}^{-1}$ in the $\mathrm{HG}$ and $\mathrm{N}$ stations, and

$1312 \times 10^{5}$ cells $\mathrm{mL}^{-1}$ in the EG stations. Within the bacterial communities, a combination of classes that are functionally associated with phytoplankton blooms in the region (Bacteroidia, Gammaproteobacteria, and the phylum Verrucomicrobia) (Fadeev et al., 2018) showed several-fold higher cell abundances in the $\mathrm{HG}$ and $\mathrm{N}$ stations $\left(2.3-10 \times 10^{5}\right.$ cells $\left.\mathrm{mL}^{-1}\right)$, compared to the EG stations $\left(0.5-1.5 \times 10^{5}\right.$ cells $\left.\mathrm{mL}^{-1}\right)$. Jointly, these classes comprised up to $50 \%$ of the analyzed bacterioplankton communities (Table 1). Other taxonomic groups, which were previously associated with the Arctic water masses and winter communities in the Fram Strait (e.g., the class Deltaproteobacteria and the Thaumarchaeota) (Wilson et al., 2017; Fadeev et al., 2018, 2020; Müller et al., 2018b), showed higher cell abundances in the ice-covered EG stations, as compared to the ice-free HG and ice-margin N stations (Table 1). Hence, the spatial variability in cell abundances of different taxonomic groups was apparently associated with different stages of the phytoplankton bloom and different water masses.

To further test the link with distinct bloom conditions or distinct physical conditions in Atlantic vs. Arctic water masses, we conducted specific correlation tests between the cell abundances of different taxonomic groups, temperature and salinity (Table S2), which define the distinct water masses in the Fram Strait. We identified that cell abundances of Verrucomicrobia and its order Opitutales, as well as the SAR11 clade and the Rhodobacteraceae family (both members of the class Alphaproteobacteria), showed significant positive correlations to water temperature (Pearson's correlation; $r>0.5, p$-value $<0.05$; Table $\mathrm{S} 2$ ), suggesting an association with the warmer Atlantic waters of the eastern Fram Strait. The Verrucomicrobia has been previously shown to be a major polysaccharide-degrading bacterial taxonomic group in Svalbard fjords (Cardman et al., 2014), and therefore may also be associated with the outflow from the Svalbard fjords into the Atlantic waters of the WSC (Cottier et al., 2005). The SAR11 clade and the Rhodobacteraceae have both been previously shown to correlate with temperature at high latitudes (Giebel et al., 2011; Tada et al., 2013), and are known to have distinct phylotypes in water masses with different temperatures (Selje et al., 2004; Sperling et al., 2012; Giovannoni, 2017). However, the Rhodobacteraceae are also known for their broad abilities in utilizing organic compounds (Buchan et al., 2014; Luo and Moran, 2014). Thus, one cannot rule out that their higher cell abundances in warmer waters of the HG and $\mathrm{N}$ stations are associated with the late stage of the phytoplankton bloom and their exudates. In addition, the SAR324 clade (Deltaproteobacteria) showed strong positive correlation with statistical significance to salinity (Pearson's correlation; $r>0.5, p$-value $<0.05$; Table S2). During the summer, with increased melting of sea ice, a low-salinity water layer is formed in surface waters, and the strong stratification of this water layer enhances the development of the phytoplankton bloom (Fadeev et al., 2018). Consequently, the correlation of SAR324 with higher salinity suggests that their cell abundances are lower in surface waters where, in turn, we observe a strong phytoplankton bloom (e.g., in WSC).

The distinct surface water masses in the region differ not only in their physical but also in their biogeochemical characteristics (Wilson and Wallace, 1990; Fadeev et al., 2018), with higher concentrations of inorganic nitrogen and phosphate in the Atlantic, compared to the Arctic water masses. At the time of sampling, the typical Redfield ratio between inorganic nitrogen (mainly nitrate $\left.\mathrm{NO}_{3}\right)$ and inorganic phosphate $\left(\mathrm{PO}_{4}\right)$ was below 16 (Redfield, 1963; Goldman et al., 1979). This suggests that the water masses were nitrogen limited across all three regions (Table S1) during summer due to phytoplankton dynamics. In order to disentangle the effect of biological consumption 
174

175

176

177

178

179

180

181

182

183

184

185

186

187

188

189

190

191

192

193

194

195

196

197

198

199

200

201

202

203

204

205

206

207

208

209

210

211

212

213

214

215

216

217

218

219

of nutrients from water mass-specific nutrient signatures, we calculated the seasonal net consumption of inorganic nutrients, as the proxy for phytoplankton bloom conditions (Table S1). Consumed nitrate $\left(\Delta \mathrm{NO}_{3}\right)$ and phosphate $\left(\Delta \mathrm{PO}_{4}\right)$ revealed a very strong positive correlation with statistical significance (Pearson's correlation; $r=0.86, p$-value $<0.05$; Table $\mathrm{S} 2$ ). The consumed silica $\left(\Delta \mathrm{SiO}_{3}\right)$, used by diatoms, did not show a significant correlation to $\Delta \mathrm{PO}_{4}$ and $\Delta \mathrm{NO}_{3}$. This further supports the impact of different phytoplankton populations across the Strait (i.e., diatoms vs. Phaeocystis; Fadeev et al., 2020). Phytoplankton bloom-associated environmental parameters (chlorophyll $a$ concentration and the consumed inorganic nutrients) revealed weaker relationships with cell abundances of different taxonomic groups (Table S2). Furthermore, we did not observe significant positive correlations of the cell abundances of diatoms or Phaeocystis spp., with the quantified bacterioplankton taxa. This might be explained by time lags and local differences in the dynamic development of phytoplankton blooms across the entire Strait (Wilson et al., 2017; Fadeev et al., 2018).

The complexity of Fram Strait surface waters with different ice-coverages, a dynamic ice-melt water layer and mesoscale mixing events of Atlantic and Polar water masses by eddies (Wekerle et al., 2017), challenges the identification of specific associations between microbial cell abundances and environmental parameters. While a mixture of all these environmental variables is likely shaping the bacterioplankton communities, our results showed that elevated cell abundances of some taxonomic groups (e.g., Gammaproteobacteria) had stronger association with phytoplankton bloom conditions observed at the site (e.g., through a link with algal exudates and nutrients as main source for growth) (Tada et al., 2011; Teeling et al., 2012). On the other hand, other taxonomic groups (e.g., SAR11 clade) were potentially more influenced by physical processes such as the presence of ice and distinct Arctic water masses (Kraemer et al., 2020).

\subsection{Bacterioplankton communities strongly change in cell abundance and composition with depth}

We found that in all three regions, total cell abundances of the entire bacterioplankton community were highest at surface with $10^{5}-10^{6}$ cells $\mathrm{mL}^{-1}$, and significantly decreased with depth down to $10^{4}$ cells $\mathrm{mL}^{-1}$ at meso- and bathypelagic depths (Figure 2a; Table S3; Kruskal-Wallis test; Chi square $=554.39, \mathrm{df}=3, p$-value $<0.01)$. Members of the domain Bacteria dominated the communities throughout the entire water column, with highest cell abundances in surface waters $\left(10^{5}-10^{6}\right.$ cells $\mathrm{mL}^{-}$ ${ }^{1}$ ), and significantly lower $10^{4}$ cells $\mathrm{mL}^{-1}$ at depth (Figure 2b; Kruskal-Wallis test; Chi square $=35.27$, $\mathrm{df}=3, p$-value $<0.01$ ). Archaeal cells had an overall lower abundance than bacterial cells by an order of magnitude throughout the entire water column, ranging from $10^{4}$ cells $\mathrm{mL}^{-1}$ at surface down to $10^{3}$ cells $\mathrm{mL}^{-1}$ in bathypelagic waters (Figure 2c). However, unlike Bacteria, archaeal communities doubled their absolute cell abundances from ca. $3 \times 10^{4}$ cells $\mathrm{mL}^{-1}$ at surface to ca. $6 \times 10^{4}$ cells $^{-1}$ at $100 \mathrm{~m}$ depth, followed by a significant decrease in cell abundance at meso- and bathypelagic depths (Kruskal-Wallis test; Chi square $=29.04, \mathrm{df}=3, p$-value $<0.01$ ). Compared to the stronger decline in bacterial cell numbers, this pattern mirrors the known global trend of relative archaeal enrichment in epipelagic waters (Karner et al., 2001; Herndl et al., 2005; Kirchman et al., 2007; Varela et al., 2008; Schattenhofer et al., 2009), and was also observed in other regions of the Arctic Ocean (Amano-Sato et al., 2013). Altogether, observed here bacterioplankton cell abundances in surface waters were well within the range of previous observations in the Fram Strait waters, conducted using flow cytometry (Piontek et al., 2014; Fadeev et al., 2018; Engel et al., 2019). However, compared to recent CARDFISH based observations in eastern Fram Strait (Quero et al., 2020), cell abundances were consistently one order of magnitude lower along the entire water column. The discrepancy might be associated with methodological differences, such as shorter staining times and the usage of an 
automated over a manual counting approach in our study. Nevertheless, both studies showed a similar pattern of a strong decrease in bacterioplankton cell abundances with depth, which also matches observations in other oceanic regions (Karner et al., 2001; Church et al., 2003; Teira et al., 2004; Schattenhofer et al., 2009; Dobal-Amador et al., 2016).

224 In surface waters of all stations, ca. $60 \%$ of DAPI-stained total bacterioplankton community was covered by the Bacteria-specific probes (EUB388 I-III; Table S3). At depth ( $>100 \mathrm{~m})$, the coverage of total cells by the Bacteria-specific probes strongly decreased to $16-40 \%$ of DAPI-stained cells (ANOVA; $F_{3}=15.39, p<0.01$; Table S3). A similar decrease in detectability of the domain-specific probes was previously observed in other bacterioplankton microscopy studies (Karner et al., 2001; Herndl et al., 2005; Varela et al., 2008), and reasons may lie in a ribosomal nucleic acid concentration decrease within the bacterial cells (i.e., lower activity) towards the oligotrophic depths. In addition, there is a potential increase with greater water depths of microbial phylogenetic groups that are not captured by the currently existing probes (Hewson et al., 2006; Galand et al., 2009a; Agogué et al., 2011; Welch and Huse, 2011; Salazar et al., 2016).

234 Interestingly, the Archaea-specific probe (ARCH915) showed a different trend. In surface waters, the

235

236 coverage of the probe was higher in the ice-covered EG stations ( $8 \%$ of DAPI-stained cells), compared to ice-free HG and ice-margin N stations (1-2\% of DAPI-stained cells; Table S3). With depth $(>100 \mathrm{~m})$, in EG stations the coverage of the probe increased ca. twofold, while in HG and $\mathrm{N}$ stations the coverage of the probe increased ca. tenfold. Overall, across all three regions, coverage of the Archaea-specific probe was significantly higher at depth (ANOVA; $F_{3}=34.31, p<0.01$ ), reaching $13-17 \%$ of DAPI-stained cells (Table S3). This trend implies an increase in relative abundance of Archaea with depth (Müller et al., 2018a; Fadeev et al., 2020). Taken together, our findings confirm previously observed higher abundances of Archaea in bacterioplankton communities of ice-covered waters (Wilson et al., 2017; Müller et al., 2018b; Fadeev et al., 2020), and correspond to the globally observed trend of an increasing archaeal importance at depth (Herndl et al., 2005; Teira et al., 2006; Galand et al., 2009b).

\subsection{Enigmatic microbial lineages increase in cell abundance towards the deep ocean}

The deep waters of the Fram Strait basin $(>500 \mathrm{~m}$ ) have a rather homogeneous hydrography (von Appen et al., 2015), and are less affected by the seasonal dynamics that govern the surface layers (Wilson et al., 2017). Previous molecular observations of the deep water bacterioplankton communities showed high sequence abundances of largely unknown taxonomic groups, such as the SAR202 (class Dehalococcoidia), SAR324 (Deltaproteobacteria), and SAR406 (phylum Marinimicrobia) (Wilson et al., 2017; Fadeev et al., 2020; Quero et al., 2020). There was also higher archaeal sequence abundance at depth, with the class Nitrososphaeria reaching up to $15 \%$ of the sequences in mesopelagic waters (> $200 \mathrm{~m}$ ) (Wilson et al., 2017; Müller et al., 2018b; Fadeev et al., 2020). However, it has also been recently shown that in ice-covered regions of the Strait surfacedominant taxonomic groups, such as Gammaproteobacteria and Nitrososphaeria, are exported via fast-sinking aggregates from surface to the deep ocean $(>1000 \mathrm{~m})$, where they may realize an ecological niche (Fadeev et al., 2020). We observed that in all meso- and bathypelagic waters across all analyzed regions the total cell abundances of the bacterioplankton communities were in the range of $10^{4}$ cells $\mathrm{mL}^{-1}$ (Figure 2), reflecting observations made in other regions of the Arctic Ocean (Wells and Deming, 2003; Wells et al., 2006). Bacterial taxonomic groups that dominated the surface water communities (e.g., Bacteroidetes, Gammaproteobacteria and Verrucomicrobia), in both ice-free and ice-covered regions of the Strait, decreased by two orders of magnitude in their cell abundances at meso- and bathypelagic depths (Kruskal-Wallis test; $p$-value $<0.01$; Table 2 ). This trend strongly 
correlated with the total bacterioplankton cell abundances along the general water column (Pearson's correlation; $r>0.8, p$-value $<0.05$; Figure S1). In contrast, other bacterial groups, such as the SAR202 and SAR324 clades, proportionally increased in cell abundances with depth, and maintained overall constant cell abundances of ca. $0.5 \times 10^{4}$ cells $\mathrm{mL}^{-1}$ until the deep basin (Table 2). Previous molecular studies of bacterioplankton communities in the Fram Strait suggested a proportional increase of these largely understudied bacterial lineages in the deep ocean, which were previously found to be associated with winterly (surface) bacterioplankton (Wilson et al., 2017; Fadeev et al., 2020). The cell abundances presented here indicate that their increasing proportional abundance at depth is due to stronger decrease in the cell abundances of other groups (Table 2; Table S4). Very little is currently known about these two taxonomic groups, but previous genetic observations suggest that they possess distinct metabolic capabilities, and may be involved in the degradation of recalcitrant organic matter (SAR202 clade; Landry et al., 2017; Colatriano et al., 2018; Saw et al., 2019), or, in sulfur oxidation (SAR324 clade; Swan et al., 2011; Sheik et al., 2014). Their homogeneous distribution from the stratified surface to the homogenous deep ocean of the Fram Strait suggests that these enigmatic bacterial groups fulfil an ecological niche that exists in the entire water column, and thus may have unique roles in oceanic nutrient cycling.

The proportional decrease of archaeal cell abundances with depth was less than that of members of the domain Bacteria (Table S4), meaning that members of the Archaea were proportionally increasing in the total microbial deep-water communities. The Thaumarchaeota strongly correlated with the pattern of the archaeal cell abundances (Pearson's correlation; $r=0.76, p$-value $<0.05$; Figure $\mathrm{S} 1)$, showing a two-fold increase in cell abundance from surface to epipelagic depth $(100 \mathrm{~m})$, followed by a substantial decrease towards meso- and bathypelagic waters (Table S4). This two-fold increase towards the epipelagic depths corresponds to previous observations of Thaumarchaeota in the north Atlantic (Müller et al., 2018b) and further increase in cell abundances at higher depths ( $>1000 \mathrm{~m}$ ) was also observed in other oceanic regions (Karner et al., 2001; Church et al., 2003; Herndl et al., 2005). It has been shown in molecular studies that Thaumarchaeota comprise a large proportion of the bacterioplankton communities in the Fram Strait, especially in the epipelagic waters (Wilson et al., 2017; Müller et al., 2018b; Fadeev et al., 2020). In our study, the Thaumarchaeota exhibited their highest cell abundances at $100 \mathrm{~m}$ in the ice-free $\mathrm{HG}$, and at the ice-margin $\mathrm{N}$ stations $\left(3 \times 10^{4}\right.$ cells $\left.\mathrm{mL}^{-1}\right)$, where they comprised half of the total archaeal community (Table S4). The strong absolute decrease of Thaumarchaeota cell abundances towards the meso- and bathypelagic waters suggests a decrease in activity with depth (Herndl et al., 2005; Kirchman et al., 2007; AlonsoSáez et al., 2012), and thus lower cell detectability. In deeper water layers, other pelagic archaeal groups, such as the phylum Euryarchaeota that was not quantified in this study, may increase in abundance and form the bulk of total archaeal cells here (Galand et al., 2010; Fadeev et al., 2020).

\section{Conclusions}

301 Using state-of-the-art semi-automatic microscopy cell counting, we quantified the absolute cell abundance of 14 key taxonomic groups in summer bacterioplankton communities of the Fram Strait. Our observations covered both the ice-free and ice-covered regions of the Strait, which at the time of sampling were characterized by different phytoplankton bloom stages. Our results showed that in surface waters, abundance of some taxonomic groups was related to the Atlantic waters (e.g., Rhodobacteraceae). The abundance of different taxonomic groups was strongly positively (e.g., Gammaproteobacteria) and negatively (e.g., SAR324 clade) associated with the states of the seasonal phytoplankton bloom across the Strait. Based on previous studies in the region, it is conceivable that there were also specific associations between the of blooming phytoplankton and different bacterioplankton taxa, however these were not observed in our analysis. This suggests that 
311 currently predicted longer seasonal phytoplankton blooms, as well as the increasing Atlantic

312 influence on the Arctic Ocean (i.e., 'Atlantification'), may have a strong impact on the composition

313

314 and biogeographical distribution of certain bacterioplankton taxonomic groups in the surface Arctic waters.

315 This study also provides the first extensive quantification of bacterioplankton communities in the

316

317

318 deep Arctic water column ( $>500 \mathrm{~m})$. We showed that with depth, some taxonomic groups, such as the SAR202 clade, maintained similar abundances throughout the entire water column $(2500 \mathrm{~m}$ depth), where other taxa decline by several-fold. This observation suggests that despite their low abundance, some taxonomic groups may potentially realize a unique ecological niche throughout the entire water column.

Altogether, our quantitative data on cell abundances of ecologically relevant taxonomic bacterioplankton groups provide insight into factors structuring pelagic bacterioplankton communities from surface to the deep waters of the Arctic Ocean and a baseline to better assess future changes in a rapidly warming region.

\section{Materials and Methods}

\subsection{Sampling and environmental data collection}

Sampling was carried out during the RV Polarstern expedition PS99.2 to the Long-Term Ecological

328 Research (LTER) site HAUSGARTEN in Fram Strait (June 24th - July 16th, 2016). Sampling was

329

330 carried out with 12 L Niskin bottles mounted on a CTD rosette (Sea-Bird Electronics Inc. SBE 911 plus probe) equipped with temperature and conductivity sensors, a pressure sensor, altimeter, and a chlorophyll fluorometer. On board, the samples were fixed with formalin in a final concentration of $2 \%$ for $10-12$ hours, then filtered onto $0.2 \mu \mathrm{m}$ polycarbonate Nucleopore Track-Etched filters

333 (Whatman, Buckinghamshire, UK), and stored at $-20^{\circ} \mathrm{C}$ for further analysis.

Hydrographic data of the seawater including temperature and salinity were retrieved from

PANGAEA (Schröder and Wisotzki, 2014), along with measured chlorophyll $a$ concentration (Nöthig et al., 2018; Fadeev et al., 2020) (Table S1).

\subsection{Catalyzed reporter deposition-fluorescence in situ hybridization (CARD-FISH)}

We quantified absolute cell abundances of 14 key bacterioplankton groups (Table S5), based on their relatively high sequence abundance and recurrences in previous molecular studies of Arctic waters (Bowman et al., 2012; Wilson et al., 2017; Müller et al., 2018b; Fadeev et al., 2020). CARD-FISH was applied based on the protocol established by (Pernthaler et al., 2002), using horseradishperoxidase (HRP)-labelled oligonucleotide probes (Biomers.net, Ulm, Germany). All probes were checked for specificity and coverage of their target groups against the SILVA database release 132 (Quast et al., 2013). All filters were embedded in 0.2\% low-gelling-point agarose, and treated with 10 $\mathrm{mg} \mathrm{mL} \mathrm{mL}^{-1}$ lysozyme solution (Sigma-Aldrich Chemie GmbH, Hamburg, Germany) for $1 \mathrm{~h}$ at $37^{\circ} \mathrm{C}$. Filters for enumerating Archaea and Thaumarchaeota were treated for an additional 30 min in $36 \mathrm{U}$ $\mathrm{mL}^{-1}$ achromopeptidase (Sigma-Aldrich Chemie GmbH, Hamburg, Germany) and $15 \mu \mathrm{g} \mathrm{mL}^{-1}$ proteinase $\mathrm{K}$ at $37^{\circ} \mathrm{C}$. Subsequently, endogenous peroxidases were inactivated by submerging the filter pieces in $0.15 \% \mathrm{H}_{2} \mathrm{O}_{2}$ in methanol for 30 min before rinsing in Milli-Q water and dehydration in $96 \%$ ethanol. Then, the filters were covered in hybridization buffer and a probe concentration of $0.2 \mathrm{ng} \mu \mathrm{L}^{-1}$. Hybridization was performed at $46^{\circ} \mathrm{C}$ for $2.5 \mathrm{~h}$, followed by washing in pre-warmed washing buffer at $48^{\circ} \mathrm{C}$ for $10 \mathrm{~min}$, and $15 \mathrm{~min}$ in $1 \mathrm{x}$ PBS. Signal amplification was carried out for 
$45 \mathrm{~min}$ at $46^{\circ} \mathrm{C}$ with amplification buffer containing either tyramide-bound Alexa $488(1 \mu \mathrm{g} / \mathrm{mL})$ or Alexa $594\left(0.33 \mu \mathrm{g} \mathrm{mL}^{-1}\right)$. Afterwards, the cells were counterstained in $1 \mu \mathrm{g} / \mathrm{mL}$ DAPI $\left(4^{\prime}, 6-\right.$ diamidino-2-phenylindole; Thermo Fisher Scientific GmbH, Bremen, Germany) for $10 \mathrm{~min}$ at $46^{\circ} \mathrm{C}$. After rinsing with Milli-Q water and 96\% ethanol, the filter pieces were embedded in a 4:1 mix of Citifluor (Citifluor Ltd, London, United Kingdom) and Vectashield (Vector Laboratories, Inc., Burlingame, United States), and stored overnight at $-20^{\circ} \mathrm{C}$ for later microscopy evaluation.

\subsection{Automated image acquisition and cell counting}

The filters were evaluated microscopically under a Zeiss Axio Imager.Z2 stand (Carl Zeiss MicroImaging $\mathrm{GmbH}$, Jena, Germany), equipped with a multipurpose fully automated microscope imaging system (MPISYS), a Colibri LED light source illumination system, and a multi-filter set 62HE (Carl Zeiss MicroImaging GmbH, Jena, Germany). Pictures were taken via a cooled chargedcoupled-device (CCD) camera (AxioCam MRm; Carl Zeiss AG, Oberkochen, Germany) with a 63× oil objective, a numerical aperture of 1.4 , and a pixel size of $0.1016 \mu \mathrm{m} /$ pixel, coupled to the AxioVision SE64 Rel.4.9.1 software (Carl Zeiss AG, Oberkochen, Germany) as described by (Bennke et al., 2016). Exposure times were adjusted after manual inspection with the AxioVision Rel.4.8 software coupled to the SamLoc 1.7 software (Zeder et al., 2011), which was also used to define the coordinates of the filters on the slides. For image acquisition, channels were defined with the MPISYS software, and a minimum of 55 fields of view with a minimum distance of $0.25 \mathrm{~mm}$ were acquired of each filter piece by recoding a z-stack of 7 images in autofocus.

Cell enumeration was performed with the software Automated Cell Measuring and Enumeration Tool (ACMETool3, 2018-11-09; M. Zeder, Technobiology GmbH, Buchrain, Switzerland). Cells were counted as objects according to manually defined parameters separately for the DAPI and FISH channels.

\subsection{Calculation of consumed inorganic nutrients}

Following (Fadeev et al., 2018) the nutrient consumption $(\Delta)$ at each station was calculated by subtracting the mean value of all collected measurements above $50 \mathrm{~m}$ from the mean value of all collected measurements between 50 and $100 \mathrm{~m}$ (below the seasonal pycnocline).

\subsection{Statistical analyses}

All statistical analyses and calculations in this study were performed using R (v4.0.2) (www.rproject.org) in RStudio (v1.3.1056), i.e. statistical tests for normality, ANOVA and Kruskal-Wallis. Post-hoc Wilcoxon test and Pearson's rank correlation coefficient were conducted with the R package "rstatix" (v0.6.0) (Kassambara, 2020). Plots were generated using the R package "ggplot2" (v3.3.2) (Wickham, 2016) and "tidyverse" (v1.3.0) (Wickham et al., 2019).

\subsection{Data availability}

All data is accessible via the Data Publisher for Earth \& Environmental Science PANGAEA (www.pangaea.de): cell abundances under doi:10.1594/PANGAEA.905212, and inorganic nutrient measurements under doi:10.1594/PANGAEA.906132. Scripts for processing the data can be accessed at https://github.com/edfadeev/FramStrait-counts.

\subsection{Conflict of Interest}


The authors declare that the research was conducted in the absence of any commercial or financial relationships that could be construed as a potential conflict of interest.

\section{Author contributions}

395

396

397

398

399

400

401

402

403

404

MC-M, EF and VS-C designed and conducted the study. MC-M, EF and VS-C wrote the manuscript with guidance from $\mathrm{AB}$. All authors critically revised the manuscript and gave their approval of the submitted version.

\section{$6 \quad$ Funding}

This project has received funding from the European Research Council (ERC) under the European Union's Seventh Framework Program (FP7/2007-2013) research project ABYSS (Grant Agreement no. 294757) to AB. Additional funding came from the Helmholtz Association, specifically for the FRAM infrastructure, from the Max Planck Society, from the Hector Fellow Academy, and from the Austrian Science Fund (FWF) grant no. M-2797 to EF. This publication is Eprint ID 51358 of the Alfred Wegener Institute Helmholtz Center for Polar and Marine Research, Bremerhaven, Germany.

\section{$7 \quad$ Acknowledgements}

We thank the captain and crew of RV Polarstern expedition PS99.2, as well as the chief scientist Thomas Soltwedel for support with work at sea. We also thank Pier Offre for assistance in sampling, Greta Reintjes for designing the probe Opi346, Mareike Bach for technical support, Sinhue TorresValdes and Laura Wischnewski for conducting the inorganic nutrient measurements. We thank Andreas Ellrott for the support with the automated microscope from the Max Planck Institute for Marine Microbiology. This work was conducted in the framework of the HGF Infrastructure Program FRAM of the Alfred-Wegener-Institute Helmholtz Center for Polar and Marine.

\section{$8 \quad$ References}

Agogué, H., Lamy, D., Neal, P. R., Sogin, M. L., and Herndl, G. J. (2011). Water mass-specificity of bacterial communities in the North Atlantic revealed by massively parallel sequencing. Mol. Ecol. 20, 258-274. doi:10.1111/j.1365-294X.2010.04932.x.

Alonso-Sáez, L., Waller, A. S., Mende, D. R., Bakker, K., Farnelid, H., Yager, P. L., et al. (2012). Role for urea in nitrification by polar marine Archaea. Proc. Natl. Acad. Sci. U. S. A. 109, 17989-17994. doi:10.1073/pnas.1201914109.

Amann, R. I., Binder, B. J., Olson, R. J., Chisholm, S. W., Devereux, R., and Stahl, D. A. (1990). Combination of $16 \mathrm{~S}$ rRNA-targeted oligonucleotide probes with flow cytometry for analyzing mixed microbial populations. Appl. Environ. Microbiol. 56, 1919-1925. doi:10.1128/aem.56.6.1919-1925.1990.

Amano-Sato, C., Akiyama, S., Uchida, M., Shimada, K., and Utsumi, M. (2013). Archaeal distribution and abundance in water masses of the Arctic Ocean, Pacific sector. Aquat. Microb. Ecol. 69, 101-112. doi:10.3354/ame01624.

Basedow, S. L., Sundfjord, A., von Appen, W. J., Halvorsen, E., Kwasniewski, S., and Reigstad, M. (2018). Seasonal variation in transport of Zooplankton Into the Arctic basin through the Atlantic Gateway, Fram Strait. Front. Mar. Sci. 5, 194. doi:10.3389/fmars.2018.00194. 
430

431

432

433

434

435

436

437

438

439

440

441

442

443

444

445

446

447

448

449

450

451

452

453

454

455

456

457

458

459

460

461

462

463

464

465

466

467

Bennke, C. M., Reintjes, G., Schattenhofer, M., Ellrott, A., Wulf, J., Zeder, M., et al. (2016). Modification of a high-throughput automatic microbial cell enumeration system for shipboard analyses. Appl. Environ. Microbiol. 82, 3289-3296. doi:10.1128/AEM.03931-15.

Beszczynska-Möller, A., Fahrbach, E., Schauer, U., and Hansen, E. (2012). Variability in Atlantic water temperature and transport at the entrance to the Arctic Ocean, 19972010. ICES J. Mar. Sci. 69, 852-863. doi:10.1093/icesjms/fss056.

Beszczynska-Möller, A., Woodgate, R. A., Lee, C., Melling, H., and Karcher, M. (2011). A synthesis of exchanges through the main oceanic gateways to the Arctic Ocean. Oceanography 24, 83-99. doi:10.5670/oceanog.2011.59.

Bižić-Ionescu, M., Zeder, M., Ionescu, D., Orlić, S., Fuchs, B. M., Grossart, H. P., et al. (2015). Comparison of bacterial communities on limnic versus coastal marine particles reveals profound differences in colonization. Environ. Microbiol. 17, 3500-3514. doi:10.1111/1462-2920.12466.

Boetius, A., Albrecht, S., Bakker, K., Bienhold, C., Felden, J., Fernández-Méndez, M., et al. (2013). Export of algal biomass from the melting arctic sea ice. Science (80-. ). 339, 1430-1432. doi:10.1126/science.1231346.

Bowman, J. S., Rasmussen, S., Blom, N., Deming, J. W., Rysgaard, S., and Sicheritz-Ponten, T. (2012). Microbial community structure of Arctic multiyear sea ice and surface seawater by 454 sequencing of the 16S RNA gene. ISME J. 6, 11-20. doi:10.1038/ismej.2011.76.

Buchan, A., LeCleir, G. R., Gulvik, C. A., and González, J. M. (2014). Master recyclers: features and functions of bacteria associated with phytoplankton blooms. Nat. Rev. Microbiol. 12, 686-698. doi:10.1038/nrmicro3326.

Cardman, Z., Arnosti, C., Durbin, A., Ziervogel, K., Cox, C., Steen, A. D., et al. (2014). Verrucomicrobia are candidates for polysaccharide-degrading bacterioplankton in an Arctic fjord of Svalbard. Appl. Environ. Microbiol. 80, 3749-3756. doi:10.1128/AEM.00899-14.

Church, M. J., DeLong, E. F., Ducklow, H. W., Karner, M. B., Preston, C. M., and Karl, D. M. (2003). Abundance and distribution of planktonic Archaea and Bacteria in the waters west of the Antarctic Peninsula. Limnol. Oceanogr. 48, 1893-1902. doi:10.4319/lo.2003.48.5.1893.

Colatriano, D., Tran, P. Q., Guéguen, C., Williams, W. J., Lovejoy, C., and Walsh, D. A. (2018). Genomic evidence for the degradation of terrestrial organic matter by pelagic Arctic Ocean Chloroflexi bacteria. Commun. Biol. 1, 90. doi:10.1038/s42003-018-0086-7.

Cottier, F., Tverberg, V., Inall, M., Svendsen, H., Nilsen, F., and Griffiths, C. (2005). Water mass modification in an Arctic fjord through cross-shelf exchange: The seasonal hydrography of Kongsfjorden, Svalbard. J. Geophys. Res. Ocean. 110, 1-18. doi:10.1029/2004JC002757.

Dai, A., Luo, D., Song, M., and Liu, J. (2019). Arctic amplification is caused by sea-ice loss under increasing $\mathrm{CO}_{2}$. Nat. Commun. 10, 121. doi:10.1038/s41467-018-07954-9.

de Steur, L., Hansen, E., Gerdes, R., Karcher, M., Fahrbach, E., and Holfort, J. (2009). Freshwater fluxes in the East Greenland Current: A decade of observations. Geophys. Res. Lett. 36, L23611. doi:10.1029/2009GL041278. 
DeLong, E. F., Taylor, L. T., Marsh, T. L., and Preston, C. M. (1999). Visualization and enumeration of marine planktonic archaea and bacteria by using polyribonucleotide probes and fluorescent in situ hybridization. Appl. Environ. Microbiol. 65, 5554-5563. doi:10.1128/aem.65.12.55545563.1999 .

Dobal-Amador, V., Nieto-Cid, M., Guerrero-Feijoo, E., Hernando-Morales, V., Teira, E., and VarelaRozados, M. M. (2016). Vertical stratification of bacterial communities driven by multiple environmental factors in the waters $(0-5000 \mathrm{~m})$ off the Galician coast (NW Iberian margin). Deep. Res. Part I Oceanogr. Res. Pap. 114, 1-11. doi:10.1016/j.dsr.2016.04.009.

Dobricic, S., Vignati, E., and Russo, S. (2016). Large-scale atmospheric warming in winter and the arctic sea ice retreat. J. Clim. 29, 2869-2888. doi:10.1175/JCLI-D-15-0417.1.

Engel, A., Bracher, A., Dinter, T., Endres, S., Grosse, J., Metfies, K., et al. (2019). Inter-annual variability of organic carbon concentrations in the eastern Fram Strait during summer (20092017). Front. Mar. Sci. 6, 187. doi:10.3389/fmars.2019.00187.

Engel, A., Piontek, J., Metfies, K., Endres, S., Sprong, P., Peeken, I., et al. (2017). Inter-annual variability of transparent exopolymer particles in the Arctic Ocean reveals high sensitivity to ecosystem changes. Sci. Rep. 7, 4129. doi:10.1038/s41598-017-04106-9.

Fadeev, E., Rogge, A., Ramondenc, S., Nöthig, E.-M., Wekerle, C., Bienhold, C., et al. (2020). Seaice retreat may decrease carbon export and vertical microbial connectivity in the Eurasian Arctic basins. Nat. Res. doi:10.21203/rs.3.rs-101878/v1.

Fadeev, E., Salter, I., Schourup-Kristensen, V., Nöthig, E. M., Metfies, K., Engel, A., et al. (2018). Microbial communities in the east and west fram strait during sea ice melting season. Front. Mar. Sci. 5, 429. doi:10.3389/fmars.2018.00429.

Fernández-Méndez, M., Wenzhöfer, F., Peeken, I., Sørensen, H. L., Glud, R. N., and Boetius, A. (2014). Composition, buoyancy regulation and fate of ice algal aggregates in the Central Arctic Ocean. PLoS One 9, e107452-e107452. doi:10.1371/journal.pone.0107452.

Galand, P. E., Casamayor, E. O., Kirchman, D. L., and Lovejoy, C. (2009a). Ecology of the rare microbial biosphere of the Arctic Ocean. Proc. Natl. Acad. Sci. U. S. A. 106, 22427-22432. doi:10.1073/pnas.0908284106.

Galand, P. E., Casamayor, E. O., Kirchman, D. L., Potvin, M., and Lovejoy, C. (2009b). Unique archaeal assemblages in the arctic ocean unveiled by massively parallel tag sequencing. ISME J. 3, 860-869. doi:10.1038/ismej.2009.23.

Galand, P. E., Potvin, M., Casamayor, E. O., and Lovejoy, C. (2010). Hydrography shapes bacterial biogeography of the deep Arctic Ocean. ISME J. 4, 564-576. doi:10.1038/ismej.2009.134.

Giebel, H. A., Kalhoefer, D., Lemke, A., Thole, S., Gahl-Janssen, R., Simon, M., et al. (2011). Distribution of Roseobacter RCA and SAR11 lineages in the North Sea and characteristics of an abundant RCA isolate. ISME J. 5, 8-19. doi:10.1038/ismej.2010.87.

Giovannoni, S. J. (2017). SAR11 Bacteria: The Most Abundant Plankton in the Oceans. Ann. Rev. Mar. Sci. 9, 231-255. doi:10.1146/annurev-marine-010814-015934. 
506

507

508

509

510

511

512

513

514

515

516

517

518

519

520

521

522

523

524

525

526

527

528

529

530

531

532

533

534

535

536

537

538

539

540

541 542

Gloor, G. B., Macklaim, J. M., Pawlowsky-Glahn, V., and Egozcue, J. J. (2017). Microbiome datasets are compositional: And this is not optional. Front. Microbiol. 8, 2224. doi:10.3389/fmicb.2017.02224.

Goldman, J. C., McCarthy, J. J., and Peavey, D. G. (1979). Growth rate influence on the chemical composition of phytoplankton in oceanic waters. Nature 279, 210-215. doi:10.1038/279210a0.

Hebbeln, D., and Wefer, G. (1991). Effects of ice coverage and ice-rafted material on sedimentation in the Fram Strait. Nature 350, 409-411. doi:10.1038/350409a0.

Herndl, G. J., Reinthaler, T., Teira, E., Van Aken, H., Veth, C., Pernthaler, A., et al. (2005). Contribution of Archaea to total prokaryotic production in the deep atlantic ocean. Appl. Environ. Microbiol. 71, 2303-2309. doi:10.1128/AEM.71.5.2303-2309.2005.

Hewson, I., Steele, J. A., Capone, D. G., and Fuhrman, J. A. (2006). Remarkable heterogeneity in meso- and bathypelagic bacterioplankton assemblage composition. Limnol. Oceanogr. 51, 1274-1283. doi:10.4319/lo.2006.51.3.1274.

Karner, M. B., Delong, E. F., and Karl, D. M. (2001). Archaeal dominance in the mesopelagic zone of the Pacific Ocean. Nature 409, 507-510. doi:10.1038/35054051.

Kassambara, A. (2020). rstatix: Pipe-friendly framework for basic statistical tests. R package version 0.5.0.999. R Packag. version 0.6.0, https://rpkgs.datanovia.com/rstatix/.

Kirchman, D. L., Elifantz, H., Dittel, A. I., Malmstrom, R. R., and Cottrell, M. T. (2007). Standing stocks and activity of Archaea and Bacteria in the western Arctic Ocean. Limnol. Oceanogr. 52, 495-507. doi:10.4319/10.2007.52.2.0495.

Korhonen, M., Rudels, B., Marnela, M., Wisotzki, A., and Zhao, J. (2013). Time and space variability of freshwater content, heat content and seasonal ice melt in the Arctic Ocean from 1991 to 2011. Ocean Sci. 9, 1015-1055. doi:10.5194/os-9-1015-2013.

Kraemer, S., Ramachandran, A., Colatriano, D., Lovejoy, C., and Walsh, D. A. (2020). Diversity and biogeography of SAR11 bacteria from the Arctic Ocean. ISME J. 14, 79-90. doi:10.1038/s41396-019-0499-4.

Kumar, M. S., Slud, E. V., Okrah, K., Hicks, S. C., Hannenhalli, S., and Bravo, H. C. (2017). Analysis and correction of compositional bias in sparse sequencing count data. bioRxiv 19, 799 . doi:10.1101/142851.

Landry, Z., Swa, B. K., Herndl, G. J., Stepanauskas, R., and Giovannoni, S. J. (2017). SAR202 genomes from the dark ocean predict pathways for the oxidation of recalcitrant dissolved organic matter. MBio 8, e00413-17. doi:10.1128/mBio.00413-17.

Leu, E., Søreide, J. E., Hessen, D. O., Falk-Petersen, S., and Berge, J. (2011). Consequences of changing sea-ice cover for primary and secondary producers in the European Arctic shelf seas: Timing, quantity, and quality. Prog. Oceanogr. 90, 18-32. doi:10.1016/j.pocean.2011.02.004.

Luo, H., and Moran, M. A. (2014). Evolutionary Ecology of the Marine Roseobacter Clade. Microbiol. Mol. Biol. Rev. 78, 1-16. doi:10.1128/mmbr.88888-88. 
543

544

545

546
Müller, O., Seuthe, L., Bratbak, G., and Paulsen, M. L. (2018a). Bacterial response to permafrost derived organic matter input in an Arctic Fjord. Front. Mar. Sci. 5. doi:10.3389/fmars.2018.00263.

Müller, O., Wilson, B., Paulsen, M. L., Ruminska, A., Armo, H. R., Bratbak, G., et al. (2018b). Spatiotemporal dynamics of ammonia-oxidizing Thaumarchaeota in Distinct Arctic water masses. Front. Microbiol. 9, 24. doi:10.3389/fmicb.2018.00024.

Mundy, C. J., Barber, D. G., and Michel, C. (2005). Variability of snow and ice thermal, physical and optical properties pertinent to sea ice algae biomass during spring. J. Mar. Syst. 58, 107-120. doi:10.1016/j.jmarsys.2005.07.003.

Nöthig, E.-M., Knüppel, N., and Lorenzen, C. (2018). Chlorophyll a measured on water bottle samples during POLARSTERN cruise PS99.2 (ARK-XXX/1.2). PANGAEA doi:10.1594/PANGAEA.887855.

Nöthig, E. M., Bracher, A., Engel, A., Metfies, K., Niehoff, B., Peeken, I., et al. (2015). Summertime plankton ecology in fram strait-a compilation of long-and short-term observations. Polar Res. 34, 23349. doi:10.3402/polar.v34.23349.

Owrid, G., Socal, G., Civitarese, G., Luchetta, A., Wiktor, J., Nöthig, E. M., et al. (2000). Spatial variability of phytoplankton, nutrients and new production estimates in the waters around Svalbard. Polar Res. 19, 155-171. doi:10.1111/j.1751-8369.2000.tb00340.x.

Peng, G., and Meier, W. N. (2018). Temporal and regional variability of Arctic sea-ice coverage from satellite data. Ann. Glaciol. 59, 191-200. doi:10.1017/aog.2017.32.

Pernthaler, A., Pernthaler, J., and Amann, R. (2002). Fluorescence in situ hybridization and catalyzed reporter deposition for the identification of marine bacteria. Appl. Environ. Microbiol. 68, 30943101. doi:10.1128/AEM.68.6.3094-3101.2002.

Perrette, M., Yool, A., Quartly, G. D., and Popova, E. E. (2011). Near-ubiquity of ice-edge blooms in the Arctic. Biogeosciences 8, 515-524. doi:10.5194/bg-8-515-2011.

Piontek, J., Sperling, M., Nöthig, E. M., and Engel, A. (2014). Regulation of bacterioplankton activity in Fram Strait (Arctic Ocean) during early summer: The role of organic matter supply and temperature. J. Mar. Syst. 132, 83-94. doi:10.1016/j.jmarsys.2014.01.003.

Piontek, J., Sperling, M., Nöthig, E. M., and Engel, A. (2015). Multiple environmental changes induce interactive effects on bacterial degradation activity in the arctic ocean. Limnol. Oceanogr. 60, 1392-1410. doi:10.1002/lno.10112.

Piwosz, K., Shabarova, T., Pernthaler, J., Posch, T., Šimek, K., Porcal, P., et al. (2020). Bacterial and Eukaryotic Small-Subunit Amplicon Data Do Not Provide a Quantitative Picture of Microbial Communities, but They Are Reliable in the Context of Ecological Interpretations. mSphere 5, 114. doi:10.1128/msphere.00052-20.

Polyakov, I. V., Pnyushkov, A. V., Alkire, M. B., Ashik, I. M., Baumann, T. M., Carmack, E. C., et al. (2017). Greater role for Atlantic inflows on sea-ice loss in the Eurasian Basin of the Arctic Ocean. Science (80-. ). 356, 285-291. doi:10.1126/science.aai8204. 
581

582

583

584

585

586

587

588

589

590

591

592

593

594

595

596

597

598

599

600

601

602

603

604

605

606

607

608

609

610

611

612

613

614

615

616

617

618

Quast, C., Pruesse, E., Yilmaz, P., Gerken, J., Schweer, T., Yarza, P., et al. (2013). The SILVA ribosomal RNA gene database project: Improved data processing and web-based tools. Nucleic Acids Res. 41, D590-D596. doi:10.1093/nar/gks1219.

Quero, G. M., Celussi, M., Relitti, F., Kovačević, V., Del Negro, P., and Luna, G. M. (2020). Inorganic and Organic Carbon Uptake Processes and Their Connection to Microbial Diversity in Meso- and Bathypelagic Arctic Waters (Eastern Fram Strait). Microb. Ecol. 79, 823-839. doi:10.1007/s00248-019-01451-2.

Redfield, A. C. (1963). "The influence of organisms on the composition of seawater," in The sea (Wiley-Interscience), 26-77.

Rudels, B., Schauer, U., Björk, G., Korhonen, M., Pisarev, S., Rabe, B., et al. (2012). Observations of water masses and circulation in the Eurasian Basin of the Arctic Ocean from the 1990s to the late 2000s. Ocean Sci. Discuss. 9, 2695-2747. doi:10.5194/osd-9-2695-2012.

Salazar, G., Cornejo-Castillo, F. M., Benítez-Barrios, V., Fraile-Nuez, E., Álvarez-Salgado, X. A., Duarte, C. M., et al. (2016). Global diversity and biogeography of deep-sea pelagic prokaryotes. ISME J. 10, 596-608. doi:10.1038/ismej.2015.137.

Saw, J. H. W., Nunoura, T., Hirai, M., Takaki, Y., Parsons, R., Michelsen, M., et al. (2019). Pangenomics reveal diversification of enzyme families and niche specialization in globally abundant SAR202 bacteria. bioRxiv 11. doi:10.1101/692848.

Schattenhofer, M., Fuchs, B. M., Amann, R., Zubkov, M. V., Tarran, G. A., and Pernthaler, J. (2009). Latitudinal distribution of prokaryotic picoplankton populations in the Atlantic Ocean. Environ. Microbiol. 11, 2078-2093. doi:10.1111/j.1462-2920.2009.01929.x.

Schröder, M., and Wisotzki, A. (2014). Physical oceanography measured on water bottle samples during POLARSTERN cruise PS82 (ANT-XXIX/9). doi:10.1594/PANGAEA.871952.

Selje, N., Simon, M., and Brinkhoff, T. (2004). A newly discovered Roseobacter cluster in temperate and polar oceans. Nature 427, 445-448. doi:10.1038/nature02272.

Sheik, C. S., Jain, S., and Dick, G. J. (2014). Metabolic flexibility of enigmatic SAR324 revealed through metagenomics and metatranscriptomics. Environ. Microbiol. 16, 304-317. doi:10.1111/1462-2920.12165.

Soltwedel, T., Bauerfeind, E., Bergmann, M., Bracher, A., Budaeva, N., Busch, K., et al. (2016). Natural variability or anthropogenically-induced variation? Insights from 15 years of multidisciplinary observations at the arctic marine LTER site HAUSGARTEN. Ecol. Indic. 65, 89-102. doi:10.1016/j.ecolind.2015.10.001.

Soltwedel, T., Bauerfeind, E., Bergmann, M., Budaeva, N., Hoste, E., Jaeckisch, N., et al. (2005). Hausgarten: Multidisciplinary investigations at a Deep-Sea, long-term observatory in the Arctic Ocean. Oceanography 18, 46-61. doi:10.5670/oceanog.2005.24.

Sperling, M., Giebel, H. A., Rink, B., Grayek, S., Staneva, J., Stanev, E., et al. (2012). Differential effects of hydrographic and biogeochemical properties on the SAR11 clade and Roseobacter RCA cluster in the North Sea. Aquat. Microb. Ecol. 67, 25-34. doi:10.3354/ame01580. 
619

620

621

622

623

624

625

626

627

628

629

630

631

632

633

634

635

636

637

638

639

640

641

642

643

644

645

646

647

648

649

650

651

652

653

654

655

656

657
Sun, L., Perlwitz, J., and Hoerling, M. (2016). What caused the recent "Warm Arctic, Cold Continents" trend pattern in winter temperatures? Geophys. Res. Lett. 43, 5345-5352. doi:10.1002/2016GL069024.

Swan, B. K., Martinez-Garcia, M., Preston, C. M., Sczyrba, A., Woyke, T., Lamy, D., et al. (2011). Potential for chemolithoautotrophy among ubiquitous bacteria lineages in the dark ocean. Science (80-. ). 333, 1296-1300. doi:10.1126/science.1203690.

Tada, Y., Makabe, R., Kasamatsu-Takazawa, N., Taniguchi, A., and Hamasaki, K. (2013). Growth and distribution patterns of Roseobacter/Rhodobacter, SAR11, and Bacteroidetes lineages in the Southern Ocean. Polar Biol. 36, 691-704. doi:10.1007/s00300-013-1294-8.

Tada, Y., Taniguchi, A., Nagao, I., Miki, T., Uematsu, M., Tsuda, A., et al. (2011). Differing growth responses of major phylogenetic groups of marine bacteria to natural phytoplankton blooms in the Western North Pacific Ocean. Appl. Environ. Microbiol. 77, 4055-4065. doi:10.1128/AEM.02952-10.

Teeling, H., Fuchs, B. M., Becher, D., Klockow, C., Gardebrecht, A., Bennke, C. M., et al. (2012). Substrate-controlled succession of marine bacterioplankton populations induced by a phytoplankton bloom. Science (80-. ). 336, 608-611. doi:10.1126/science.1218344.

Teeling, H., Fuchs, B. M., Bennke, C. M., Krüger, K., Chafee, M., Kappelmann, L., et al. (2016). Recurring patterns in bacterioplankton dynamics during coastal spring algae blooms. Elife 5, e11888. doi:10.7554/eLife. 11888.

Teira, E., Lebaron, P., Van Aken, H., and Herndl, G. J. (2006). Distribution and activity of Bacteria and Archaea in the deep water masses of the North Atlantic. Limnol. Oceanogr. 51, 2131-2144. doi:10.4319/1o.2006.51.5.2131.

Teira, E., Reinthaler, T., Pernthaler, A., Pernthaler, J., and Herndl, G. J. (2004). Combining catalyzed reporter deposition-fluorescence in situ hybridization and microautoradiography to detect substrate utilization by bacteria and archaea in the deep ocean. Appl. Environ. Microbiol. 70, 4411-4414. doi:10.1128/AEM.70.7.4411-4414.2004.

Varela, M. M., Van Aken, H. M., and Herndl, G. J. (2008). Abundance and activity of Chloroflexitype SAR202 bacterioplankton in the meso- and bathypelagic waters of the (sub)tropical Atlantic. Environ. Microbiol. 10, 1903-1911. doi:10.1111/j.1462-2920.2008.01627.x.

Vernet, M., Richardson, T. L., Metfies, K., Eva-Maria Nöthig, and Peeken, I. (2017). Models of plankton community changes during a warm water anomaly in Arctic waters show altered trophic pathways with minimal changes in carbon export. Front. Mar. Sci. 4, 160. doi:10.3389/fmars.2017.00160.

von Appen, W. J., Schauer, U., Somavilla, R., Bauerfeind, E., and Beszczynska-Möller, A. (2015). Exchange of warming deep waters across Fram Strait. Deep. Res. Part I Oceanogr. Res. Pap. 103, 86-100. doi:10.1016/j.dsr.2015.06.003.

Walczowski, W., Beszczynska-Möller, A., Wieczorek, P., Merchel, M., and Grynczel, A. (2017). Oceanographic observations in the Nordic Sea and Fram Strait in 2016 under the IO PAN longterm monitoring program AREX. Oceanologia 59, 187-194. doi:10.1016/j.oceano.2016.12.003. 
658

659

660

661

662

663

664

665

666

667

668

669

670

671

672

673

674

675

676

677

678

679

680

681

682

683

684

685

686
Wassmann, P., and Reigstad, M. (2011). Future Arctic Ocean seasonal ice zones and implications for pelagic-benthic coupling. Oceanography 24, 220-231. doi:10.5670/oceanog.2011.74.

Wekerle, C., Wang, Q., von Appen, W. J., Danilov, S., Schourup-Kristensen, V., and Jung, T. (2017). Eddy-Resolving Simulation of the Atlantic Water Circulation in the Fram Strait With Focus on the Seasonal Cycle. J. Geophys. Res. Ocean. 122, 8385-8405. doi:10.1002/2017JC012974.

Welch, D. B. M., and Huse, S. M. (2011). Microbial Diversity in the Deep Sea and the Underexplored "Rare Biosphere." Handb. Mol. Microb. Ecol. II Metagenomics Differ. Habitats 103, 243-252. doi:10.1002/9781118010549.ch24.

Wells, L. E., Cordray, M., Bowerman, S., Miller, L. A., Vincent, W. F., and Deming, J. W. (2006). Archaea in particle-rich waters of the Beaufort Shelf and Franklin Bay, Canadian Arctic: Clues to an allochthonous origin? Limnol. Oceanogr. 51, 47-59. doi:10.4319/1o.2006.51.1.0047.

Wells, L. E., and Deming, J. W. (2003). Abundance of bacteria, the Cytophaga-Flavobacterium cluster and Archaea in cold oligotrophic waters and nepheloid layers of the Northwest Passage, Canadian archipelago. Aquat. Microb. Ecol. 31, 19-31. doi:10.3354/ame031019.

Wickham, H. (2016). “Getting Started with ggplot2,” in ggplot2 (Springer), 11-31. doi:10.1007/9783-319-24277-4_2.

Wickham, H., Averick, M., Bryan, J., Chang, W., McGowan, L., François, R., et al. (2019). Welcome to the Tidyverse. J. Open Source Softw. 4, 1686. doi:10.21105/joss.01686.

Wilson, B., Müller, O., Nordmann, E. L., Seuthe, L., Bratbak, G., and Øvreås, L. (2017). Changes in marine prokaryote composition with season and depth over an Arctic polar year. Front. Mar. Sci. 4, 95. doi:10.3389/fmars.2017.00095.

Wilson, C., and Wallace, D. W. R. (1990). Using the nutrient ratio NO/PO as a tracer of continental shelf waters in the central Arctic Ocean. J. Geophys. Res. 95, 22193. doi:10.1029/jc095ic12p22193.

Zeder, M., Ellrott, A., and Amann, R. (2011). Automated sample area definition for high-throughput microscopy. Cytom. Part A 79 A, 306-310. doi:10.1002/cyto.a.21034. 


\section{Figures and Tables}

688 Figure 1. Oceanographic overview of the Fram Strait, including the monthly mean of sea-ice cover 689 and sea surface temperature during July 2016. The sea ice concentration is represented by inverted 690 grayscale (gray=low, white=high). Arrows represent general directions of the WSC (in red) and the 691 EGC (in blue). Stations of water column sampling are indicated and colored according to their sea692 ice conditions: ice-covered EGC stations - blue, ice-margin N stations - gray, ice-free WSC stations 693 red. The map was modified from (Fadeev et al., 2020).

694 Figure 2. Bacterioplankton cell abundances in the different regions of the Fram Strait: Total 695 bacterioplankton (A); Bacteria (B); and Archaea (C). Box plots were calculated based on cell 696 abundance. Note the different scale of the cell abundances for Archaea. The different regions are 697 indicated by color: ice-covered EGC- blue, ice-margin N - gray, ice-free WSC - red. The asterisks 698 represent levels of statistical significance of difference between all three regions per depth and 699 domain: $*<0.05, * *<0.01, * * *<0.001$. 
Table 1. Average cell abundances and proportions (\% of DAPI stained cells) of selected taxonomic groups in surface (0-30 $\mathrm{m})$ and epipelagic $(100 \mathrm{~m})$ depths of different regions across the Fram Strait. The proportions (\%) were calculated based on the total bacterioplankton cell abundances, ' $\mathrm{n}$ ' represents the number of counted fields of view. All values are represented in $10^{5}$ cells $\mathrm{mL}^{-1}$. SAR11 clade (SAR11), Gammaproteobacteria (GAM), Alteromonadaceae/Colwelliaceae/Pseudoalteromonadaceae (ATL), Bacteroidetes (BACT), Polaribacter (POL), Verrucomicrobiales (VER), Opitutales (OPI), Rhodobacteraceae (ROS), Deltaproteobacteria (DELTA), and Thaumarchaeota (THA).

\begin{tabular}{|c|c|c|c|c|c|c|c|c|c|c|c|c|c|c|c|c|}
\hline Region & $\begin{array}{l}\text { Water } \\
\text { layer }\end{array}$ & SAR11 & $\%$ & $\mathbf{n}$ & GAM & $\%$ & $\mathbf{n}$ & ALT & $\%$ & $\mathbf{n}$ & BACT & $\%$ & $\mathbf{n}$ & POL & $\%$ & $\mathbf{n}$ \\
\hline EGC & Surface & $1.9 \pm 0.7$ & 50 & 53 & $0.3 \pm 0.2$ & 13 & 67 & $0.2 \pm 0.1$ & 7 & 64 & $0.6 \pm 0.4$ & 18 & 66 & $0.4 \pm 0.3$ & 11 & 62 \\
\hline EGC & Epipelagic & $1.0 \pm 0.6$ & 26 & 50 & $0.2 \pm 0.1$ & 5 & 77 & $0.1 \pm 0.0$ & 2 & 61 & $0.3 \pm 0.2$ & 8 & 93 & $0.1 \pm 0.0$ & 2 & 52 \\
\hline $\mathrm{N}$ & Surface & $4.2 \pm 1.0$ & 24 & 81 & $2.1 \pm 0.6$ & 13 & 78 & $0.1 \pm 0.0$ & 1 & 68 & $2.1 \pm 0.8$ & 12 & 85 & $1.3 \pm 0.6$ & 8 & 85 \\
\hline $\mathrm{N}$ & Epipelagic & $2.2 \pm 0.3$ & 29 & 73 & $0.4 \pm 0.1$ & 5 & 109 & $0.2 \pm 0.1$ & 2 & 87 & $0.4 \pm 0.1$ & 6 & 102 & $0.1 \pm 0.0$ & 2 & 98 \\
\hline WSC & Surface & $6.1 \pm 2.0$ & 38 & 150 & $1.6 \pm 0.3$ & 14 & 189 & $0.3 \pm 0.1$ & 2 & 186 & $2.1 \pm 1.0$ & 16 & 163 & $0.8 \pm 0.2$ & 7 & 162 \\
\hline WSC & Epipelagic & $1.9 \pm 0.2$ & 32 & 175 & $0.2 \pm 0.0$ & 3 & 214 & $0.1 \pm 0.0$ & 1 & 186 & $0.2 \pm 0.0$ & 4 & 195 & $0.1 \pm 0.0$ & 1 & 176 \\
\hline Region & $\begin{array}{l}\text { Water } \\
\text { layer }\end{array}$ & VER & $\%$ & $\mathbf{n}$ & OPI & $\%$ & $\mathbf{n}$ & ROS & $\%$ & $\mathbf{n}$ & DELTA & $\%$ & $\mathbf{n}$ & THA & $\%$ & $\mathbf{n}$ \\
\hline EGC & Surface & $0.1 \pm 0.0$ & 3 & 41 & $0.1 \pm 0.0$ & 2 & 53 & $0.2 \pm 0.1$ & 7 & 44 & $0.2 \pm 0.1$ & 7 & 57 & $0.1 \pm 0.0$ & 3 & 34 \\
\hline EGC & Epipelagic & $0.1 \pm 0.0$ & 2 & 63 & $0.1 \pm 0.0$ & 2 & 70 & $0.3 \pm 0.2$ & 9 & 60 & $0.1 \pm 0.0$ & 4 & 67 & $0.1 \pm 0.02$ & 4 & 75 \\
\hline $\mathrm{N}$ & Surface & $0.9 \pm 0.1$ & 5 & 91 & $0.9 \pm 0.01$ & 5 & 91 & $0.6 \pm 0.0$ & 3 & 92 & $0.2 \pm 0.1$ & 1 & 86 & $0.1 \pm 0.0$ & 1 & 65 \\
\hline $\mathrm{N}$ & Epipelagic & $0.2 \pm 0.1$ & 2 & 98 & $0.2 \pm 0.1$ & 2 & 107 & $0.2 \pm 0.0$ & 3 & 108 & $0.2 \pm 0.0$ & 3 & 94 & $0.3 \pm 0.0$ & 4 & 122 \\
\hline
\end{tabular}




\section{Dynamics in Arctic bacterioplankton abundance}

\begin{tabular}{|l|l|l|l|l|l|l|l|l|l|l|l|l|l|l|l|l|}
\hline WSC & Surface & $1.1 \pm 0.0$ & 5 & 171 & $0.8 \pm 0.3$ & 5 & 172 & $0.7 \pm 0.3$ & 4 & 165 & $0.1 \pm 0.0$ & 1 & 121 & $0.1 \pm 0.0$ & 1 & 178 \\
\hline WSC & Epipelagic & $0.1 \pm 0.0$ & 2 & 219 & $0.1 \pm 0.0$ & 2 & 238 & $0.1 \pm 0.0$ & 2 & 223 & $0.2 \pm 0.1$ & 4 & 196 & $0.3 \pm 0.1$ & 5 & 246 \\
\hline
\end{tabular}




\section{Dynamics in Arctic bacterioplankton abundance}

Table 2. Average cell abundances and proportions (\% of DAPI stained cells) of selected taxonomic groups in deep water layers of the different regions across the Fram Strait. The proportions (\%) were calculated based on the total bacterioplankton cell abundances, ' $n$ ' represents the number of counted fields of view. Standard error was not calculated for samples of the EGC located in the bathypelagic zone

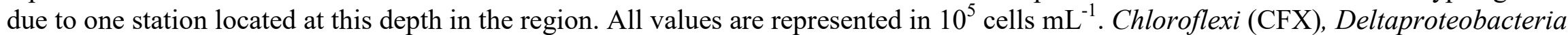
(DELTA), Thaumarchaeota (THA), Rhodobacteraceae (ROS), SAR202, SAR324, SAR406 and SAR11 clades.

\begin{tabular}{|c|c|c|c|c|c|c|c|c|c|c|c|c|c|}
\hline Region & Water layer & CFX & $\%$ & $\mathbf{n}$ & DELTA & $\%$ & $\mathbf{n}$ & THA & $\%$ & $\mathbf{n}$ & ROS & $\%$ & $\mathbf{n}$ \\
\hline EGC & Mesopelagic & $0.02 \pm 0.0$ & 5 & 57 & $0.03 \pm 0.01$ & 5 & 45 & $0.01 \pm 0.0$ & 2 & 27 & $0.1 \pm 0.0$ & 11 & 75 \\
\hline EGC & Bathypelagic & $0.02 \pm \mathrm{NA}$ & 4 & 18 & $0.02 \pm \mathrm{NA}$ & 3 & 33 & $0.01 \pm \mathrm{NA}$ & 2 & 14 & $0.03 \pm \mathrm{NA}$ & 5 & 14 \\
\hline $\mathrm{N}$ & Mesopelagic & $0.03 \pm 0.0$ & 3 & 116 & $0.04 \pm 0.0$ & 5 & 99 & $0.01 \pm 0.0$ & 1 & 28 & $0.1 \pm 0.01$ & 13 & 128 \\
\hline $\mathrm{N}$ & Bathypelagic & $0.02 \pm 0.0$ & 6 & 115 & $0.03 \pm 0.0$ & 8 & 123 & $0.01 \pm 0.0$ & 4 & 39 & $0.1 \pm 0.0$ & 20 & 122 \\
\hline WSC & Mesopelagic & $0.03 \pm 0.0$ & 3 & 217 & $0.1 \pm 0.01$ & 6 & 139 & $0.02 \pm 0.0$ & 3 & 86 & $0.1 \pm 0.01$ & 7 & 195 \\
\hline WSC & Bathypelagic & $0.02 \pm 0.0$ & 4 & 199 & $0.1 \pm 0.02$ & 9 & 130 & $0.02 \pm 0.0$ & 4 & 54 & $0.04 \pm 0.01$ & 14 & 197 \\
\hline Region & Water layer & SAR202 & $\%$ & $\mathbf{n}$ & SAR324 & $\%$ & $\mathbf{n}$ & SAR406 & $\%$ & $\mathbf{n}$ & SAR11 & $\%$ & $\mathbf{n}$ \\
\hline EGC & Mesopelagic & $0.02 \pm 0.0$ & 4 & 55 & $0.05 \pm 0.0$ & 6 & 60 & $0.01 \pm 0.0$ & 1 & 11 & $0.15 \pm 0.1$ & 22 & 49 \\
\hline EGC & Bathypelagic & $0.02 \pm \mathrm{NA}$ & 5 & 26 & $0.03 \pm \mathrm{NA}$ & 5 & 35 & $0.01 \pm \mathrm{NA}$ & 3 & 6 & $0.07 \pm \mathrm{NA}$ & 14 & 32 \\
\hline $\mathrm{N}$ & Mesopelagic & $0.03 \pm 0.0$ & 3 & 107 & $0.06 \pm 0.0$ & 6 & 66 & $0.01 \pm 0.0$ & 1 & 18 & $0.17 \pm 0.0$ & 20 & 101 \\
\hline $\mathrm{N}$ & Bathypelagic & $0.03 \pm 0.0$ & 8 & 120 & $0.03 \pm 0.0$ & 8 & 54 & $0.01 \pm 0.0$ & 3 & 37 & $0.09 \pm 0.0$ & 27 & 85 \\
\hline
\end{tabular}




\section{Dynamics in Arctic bacterioplankton abundance}

\begin{tabular}{|l|l|l|l|l|l|l|l|l|l|l|l|l|l|} 
WSC & Mesopelagic & $0.03 \pm 0.0$ & 5 & 215 & $0.05 \pm 0.0$ & 5 & 168 & $0.01 \pm 0.0$ & 2 & 37 & $0.16 \pm 0.0$ & 19 & 166 \\
\hline WSC & Bathypelagic & $0.03 \pm 0.0$ & 7 & 210 & $0.05 \pm 0.0$ & 6 & 138 & $0.01 \pm 0.0$ & 3 & 45 & $0.09 \pm 0.0$ & 21 & 201 \\
\hline
\end{tabular}




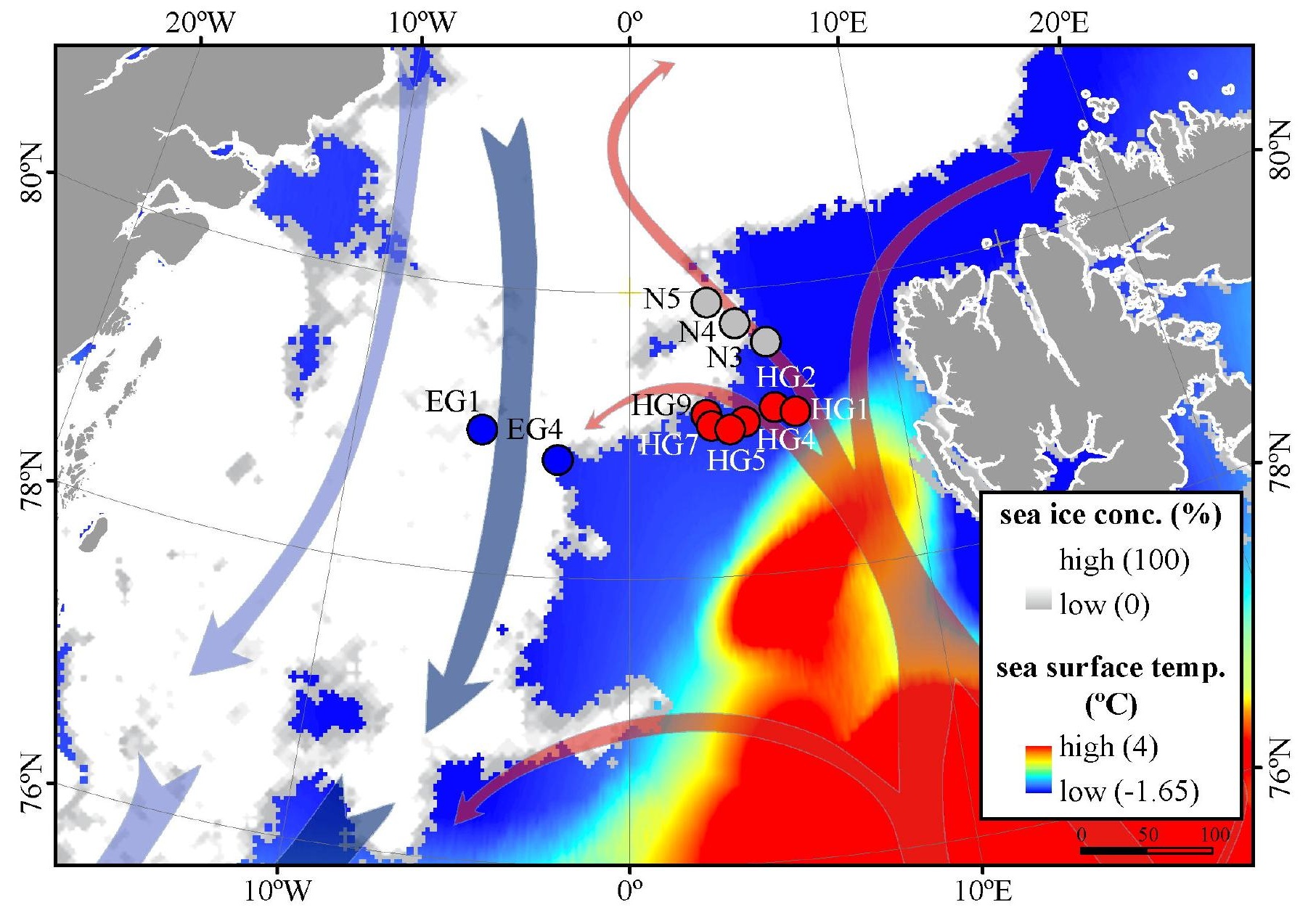


A

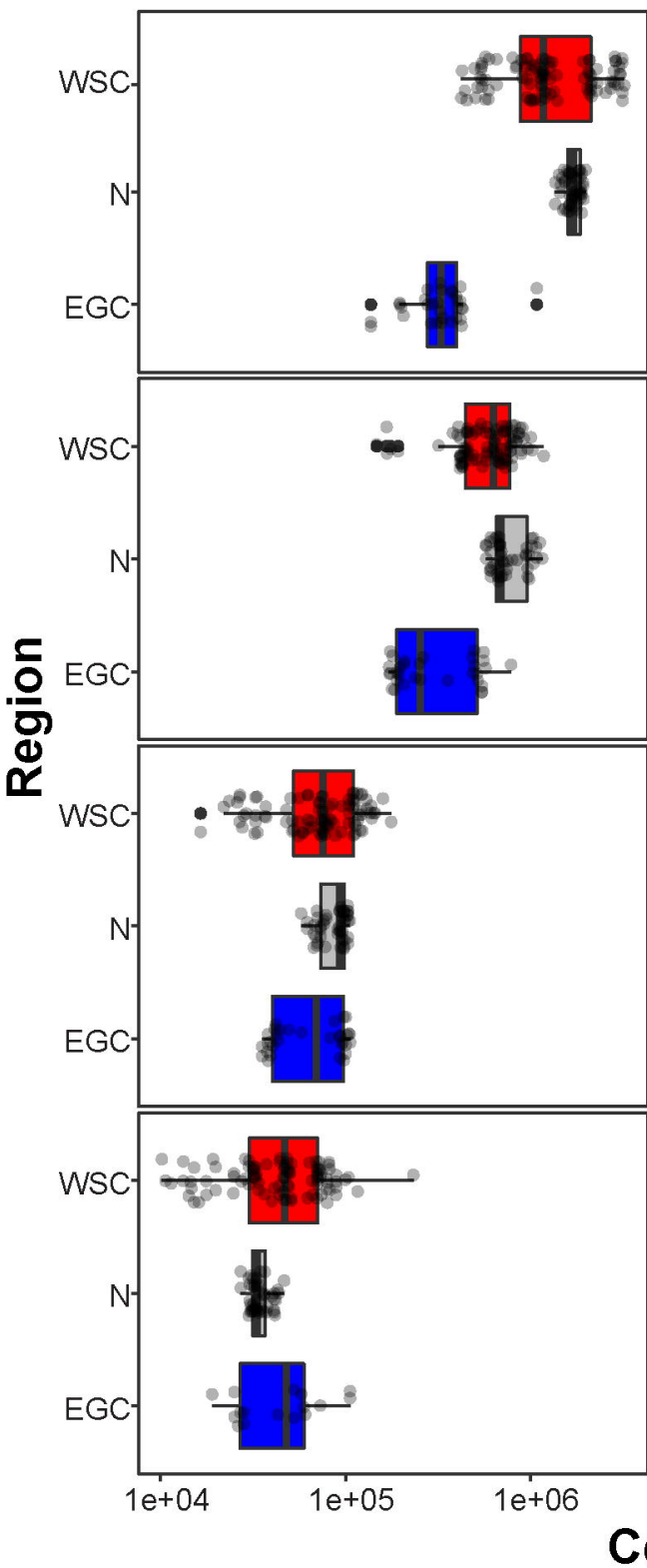

B

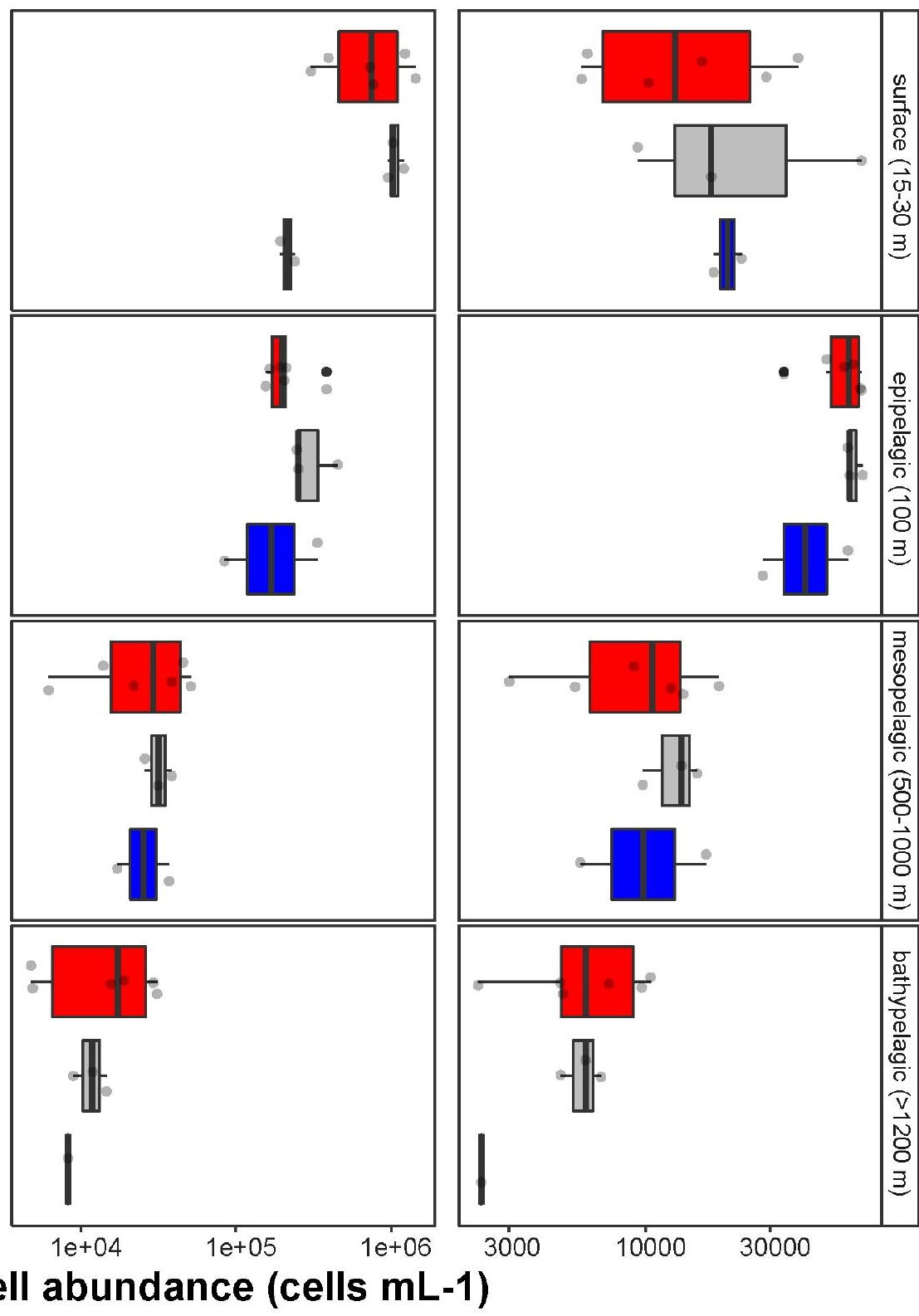

